\title{
EVALUATION OF ANTIOXIDANT, ANTIBACTERIAL, AND GAS CHROMATOGRAPHY-MASS SPECTROMETRY ANALYSIS OF ETHYL ACETATE EXTRACT OF STREPTOMYCES OMIYAENSIS SCH2
}

\author{
JANPEN TANGJITJAROENKUN* \\ Department of Basic Science and Physical Education, Faculty of Science at Sriracha, Kasetsart University, Sriracha Campus, Chonburi, \\ Thailand. Email: janpen@yahoo.com
}

Received: 07 March 2018, Revised and Accepted: 11 April 2018

\section{ABSTRACT}

Objective: The aim of this study was to evaluate the antibacterial and antioxidant properties of ethyl acetate extract of Streptomyces omiyaensis SCH2. The chemical constituents of the extract were investigated using gas chromatography-mass spectrometry (GC-MS).

Methods: Secondary metabolites from S. omiyaensis were produced by submerge fermentation using ISP2 medium with $3 \%$ NaCl (w/v) for 21 days. The culture filtrate was extracted with ethyl acetate. The chemical constituents were detected in the GC-MS analysis. Antibacterial activity was performed using disc diffusion and broth microdilution methods. Antioxidant activity was evaluated by determining the reducing power capacity and free radical scavenging assays.

Results: The GC-MS analysis of the SCH2 extract revealed the presence of four compounds. The main constituents were 2-phenylacetamide (79\%). The extract exhibited the highest zone of inhibition against some pathogenic bacteria such as Enterobacter cloacae, Klebsiella pneumoniae, and Bacillus subtilis. In addition, the lowest minimum inhibitory concentration (MIC) and minimum bactericidal concentration (MBC) values of extract were obtained for E. cloacae $(0.125$ and $4 \mathrm{mg} / \mathrm{ml})$. The extract showed antioxidant potential with $\mathrm{IC}_{50}$ values of $2,078.13 \pm 24.58 \mu \mathrm{g} / \mathrm{ml}$ and $475.74 \pm 4.56 \mu \mathrm{g} /$ $\mathrm{ml}$ for 2,2-diphenyl-1-picryl-hydrazyl and 2,2'-azino-bis[3-ethylbenzothiazoline-6-sulphonic acid] assays, respectively. The ferric reducing antioxidant power value of extract was $110.36 \pm 1.75 \mathrm{mmol} \mathrm{FeSO}_{4} \cdot 7 \mathrm{H}_{2} \mathrm{O} / \mathrm{g}$ extract.

Conclusion: This study indicated that S. omiyaensis extract possesses antibacterial and antioxidant activities. GC-MS analysis revealed the presence of major chemical constituents, acetamide, and pyrrolopyrazine which could be responsible for the biological activities. S. omiyaensis extract could be used as a potential of natural antibacterial and antioxidant agents for pharmaceutical and medical applications.

Keywords: Streptomyces omiyaensis, Antioxidant, Antibacterial, Gas chromatography-mass spectrometry (GC-MS)

(c) 2018 The Authors. Published by Innovare Academic Sciences Pvt Ltd. This is an open access article under the CC BY license (http://creativecommons. org/licenses/by/4. 0/) DOIttp://dx.doi.org/10.22159/ajpcr.2018.v11i7.25692

\section{INTRODUCTION}

Microbialsecondarymetabolites are the source of bioactivecompounds acting as antibiotics, anticancer agents, hypocholesterolemic drugs, herbicides, pesticides, and others [1]. The approximate number of microbial natural products is about 20,000-25,000 substances. About 10,000 of microbial metabolites have been produced by actinomycetes [2]. In particular, the genus Streptomyces produce over 7600 different compounds with various biological activities, such as antibiotics, antitumoral, antihypertensives, immunosuppressives, and other pharmaceutical compounds [3-6]. These metabolites isolated from Streptomyces belong to various classes, including: Polyketides, aminoglycoside, $\beta$-lactam, terpenoids, alkaloids, and others [7-11].

In a previous study, we isolated and identified the antimicrobial potential Streptomyces omiyaensis SCH2 from the mangrove sediment at coastal zone in Laem Sing district, Chanthaburi province, Thailand. This isolate has been shown antibacterial activity during primary screening by agar overlay method. The fermentation time point for the production of bioactive metabolites by this strain showed to be maximum in the range of 21-28 days when cultured on ISP2 broth with $3 \% \mathrm{NaCl}$. The 21 and 28 days filtrates of S. omiyaensis SCH2 exhibited high antimicrobial activity against Gram-positive bacteria by disc diffusion method [12].

In the present work focuses on the antimicrobial and antioxidant properties of S. omiyaensis SCH2 in ethyl acetate extract from the cell- free fermentation broth. The chemical constituents of extract were determined using gas chromatography-mass spectrometry (GC-MS).

\section{METHODS}

\section{Mangrove Streptomyces}

S. omiyaensis $\mathrm{SCH} 2$ was isolated from mangrove sediment sample in Laem Sing district $\left(12^{\circ} 24^{\prime} 13.14^{\prime \prime} \mathrm{N}, 102^{\circ} 9^{\prime} 16.16^{\prime \prime} \mathrm{E}\right)$, Chanthaburi, Thailand. This potent strain was characterized by morphological, physiological, biochemical, and phylogenetic traits. The partial 16S rRNA sequence analysis of the strain SCH2 has been deposited in GenBank (NCBI) database under the accession number JN585735.1. The sequence from SCH2 showed $100 \%$ identical to S. omiyaensis. The pure culture was preserved in $15 \%(\mathrm{v} / \mathrm{v})$ glycerol by freezing at $-80^{\circ} \mathrm{C}$. The cultures were maintained by subculture in yeast extract-malt extract (ISP2, International Streptomyces project medium No.2) agar slant at $4^{\circ} \mathrm{C}$ for further studies.

\section{Fermentation and extraction of crude extract}

The spore suspension of $S$. omiyaensis $\mathrm{SCH} 2$ was prepared in a sterilized solution of $0.1 \%(\mathrm{w} / \mathrm{v})$ tween 80 from cultures grown on ISP2 with $3 \%$ $\mathrm{NaCl}(\mathrm{w} / \mathrm{v})$ agar slant at $30^{\circ} \mathrm{C}$ for 7 days. The spore concentration of the suspension was adjusted to $1 \times 10^{6}$ spores $/ \mathrm{ml}$ using a hemocytometer. The inoculum was inoculated in $500 \mathrm{ml}$ conical flask containing $200 \mathrm{ml}$ of ISP2 broth with $3 \% \mathrm{NaCl}$ at $1 \%(\mathrm{v} / \mathrm{v})$. Cultures were incubated on the shaker at $150 \mathrm{rpm}$ at $30^{\circ} \mathrm{C}$ for 21 days. After incubation, the culture supernatant was obtained by filtration through Whatman No.1 filter paper. The filtrate was partitioned 2 times with equal volumes of ethyl acetate $(1: 1 \mathrm{v} / \mathrm{v})$ in a separating funnel. The aqueous phase was 
discarded, and the ethyl acetate phase was concentrated to dryness under vacuum using rotary evaporator at $50^{\circ} \mathrm{C}$ to obtain the crude extract. The dried crude extract was weighed and stored in a desiccator until use to determine the chemical composition, antimicrobial, and antioxidant activities.

\section{GC-MS analysis}

The chemical compounds of the crude ethyl acetate extract were carried out by GC-MS, using an Agilent Technologies Model 6890N coupled with a quadrupole mass selective detector model 5973 inert. The compounds were separated on $30 \mathrm{~m} \times 0.25 \mathrm{~mm} \times 0.25 \mu \mathrm{m}$ film thickness HP-5MS capillary column. The column temperature was increased from $70^{\circ} \mathrm{C}$ to $300^{\circ} \mathrm{C}$ at a rate of $4^{\circ} \mathrm{C} / \mathrm{min}$. The carrier gas was used helium with a flow rate of $1 \mathrm{ml} / \mathrm{min}$. The temperature of injector port was maintained at $240^{\circ} \mathrm{C}$. The mass spectrometer was operated at $70 \mathrm{eV}$ with a mass scan range of 40-400 amu. The extract components were identified with the mass spectral database contained within the Wiley7n library.

\section{Determination of antimicrobial activity}

\section{Test microorganisms}

Crude extract was tested for antibacterial activity against three Grampositive bacteria (Bacillus subtilis ATCC 6633, Staphylococcus aureus ATCC 25923, and Staphylococcus saprophyticus ATCC 15305) and six Gram-negative bacteria (Escherichia coli ATCC 25922, Pseudomonas aeruginosa ATCC 27853, Salmonella typhimurium ATCC 13311, Enterobacter cloacae ATCC 23355, Klebsiella pneumoniae ATCC 13883, and Proteus mirabilis DMST 8212). The bacterial cultures were maintained on Mueller-Hinton agar (MHA) at $4^{\circ} \mathrm{C}$ until testing. All strains were obtained from the Department of Medical Science Thailand Culture Collection (DMST), Ministry of Public Health, Nonthaburi, Thailand.

\section{Disc diffusion method}

The screening of the extract for antibacterial activity was evaluated using the disc diffusion assay [13]. The tested bacterial turbidity was adjusted to the $0.5 \mathrm{McF}$ arland standard, equivalent to $1.5 \times 10^{8} \mathrm{CFU} / \mathrm{ml}$. The bacterial suspension $(100 \mu \mathrm{l})$ was spread on the surface of MHA plate with sterile glass spreader. The dried extract was prepared by dissolved in absolute ethanol to make a final concentration of $10 \mathrm{mg} / \mathrm{ml}$. Then, sterile $6 \mathrm{~mm}$ diameter paper discs were impregnated with $10 \mu \mathrm{l}$ of the crude extract solution $(100 \mu \mathrm{g} / \mathrm{disc})$, air-dried and then placed on the inoculated plates. The standard antimicrobial discs with penicillin G (10 unit/disc) and chloramphenicol (30 $\mu \mathrm{g} / \mathrm{disc})$ were used as positive control. The filter discs impregnated with $10 \mu \mathrm{l}$ of absolute ethanol were used as negative control. The plates were incubated at $37^{\circ} \mathrm{C}$ for $24 \mathrm{~h}$. The antibacterial activity was evaluated by measuring the zone of inhibition surrounding the disc (in $\mathrm{mm}$ ). All experiments were carried out in triplicate.

\section{Determination of minimum inhibitory concentration (MIC) and} minimum bactericidal concentration (MBC)

The MIC and MBC of the ethyl acetate extract of SCH2 were tested in Mueller-Hinton broth (MHB) using a modified microdilution method with resazurin [14]. The bacterial suspension was adjusted by comparing with using $0.5 \mathrm{McF}$ (arland densitometer and further diluted to $1: 100\left(10^{6} \mathrm{CFU} / \mathrm{ml}\right)$ in sterile $0.85 \%$ saline. The crude extract was diluted to various concentration ranging from 0.0195 to $10 \mathrm{mg} / \mathrm{ml}$ in $50 \%(\mathrm{v} / \mathrm{v})$ dimethyl sulfoxide (DMSO). Two-fold dilutions of chloramphenicol $(0.195-100 \mu \mathrm{g} / \mathrm{ml})$ were used as a positive control. Each well included $80 \mu \mathrm{L}$ of MHB, $10 \mu \mathrm{l}$ of the diluted extracts, and $10 \mu \mathrm{l}$ of bacterial suspension. Chloramphenicol was used as a positive control while $50 \%(\mathrm{v} / \mathrm{v})$ DMSO was used as a negative control. The microtiter plates were incubated at $37^{\circ} \mathrm{C}$ for $24 \mathrm{~h}$. After incubation, $10 \mu \mathrm{l}$ of resazurin $(0.03 \%)$ in sterile water was added to evaluate the growth of tested bacteria and incubated for $3 \mathrm{~h}$. The cell viability was indicated by the observation of color changing from blue to pink. The MIC was identified as the lowest SCH2 extract or standard antibiotic concentration at which no change in color of resazurin.
MBC value was determined by subculturing $5 \mu$ of sample in wells that showed no visible growth from the MIC assay into microplates containing $100 \mu \mathrm{l}$ of MHB per well and incubated at $37^{\circ} \mathrm{C}$ for $24 \mathrm{~h}$. The lowest concentration of extract that showed no growth of bacteria after subculture was regarded as MBC value. The experiments were performed in triplicate.

\section{Determination of antioxidant activity}

2,2-diphenyl-1-picryl-hydrazyl (DPPH) radical scavenging assay The free radical scavenging activity of the extract of SCH2 strain was measured according to the free radical DPPH method [15]. The DPPH solution was performed on freshly prepared by dissolving $2.4 \mathrm{mg}$ of DPPH in 100 ml of absolute ethanol. The extractatvariousconcentrations was diluted with absolute ethanol to get sample solution. The diluted extract $(250 \mu \mathrm{l})$ was added to the DPPH solution $(250 \mu \mathrm{l})$. The reaction mixture was shaken well and then incubated at room temperature for $30 \mathrm{~min}$. The absorbance of the mixture was measured at $520 \mathrm{~nm}$ by a spectrophotometer. The mixture without the extract was used as negative control, and standard antioxidant butylated hydroxytoluene, (BHT) was used as positive control. The percentage scavenging radical was calculated using the formula:

DPPH radical scavenging activity $(\%)=\left[\left(\mathrm{A}_{\text {control }}-\mathrm{A}_{\text {sample }}\right)\right] / \mathrm{A}_{\text {sample }} \times 100$

Where $A_{\text {control }}$ is the absorbance of the negative control, and the $A_{\text {sample }}$ is the absorbance of the extract or standard. The $\mathrm{IC}_{50}$ value, which represented the concentration of extract that caused $50 \%$ scavenging of DPPH radical, was calculated from the graph plotting inhibition percentage against extract concentration. All experiments were carried out in triplicate.

\section{2,2'-azino-bis[3-ethylbenzothiazoline-6-sulphonic acid] (ABTS) free radical scavenging assay}

The free radical $\mathrm{ABTS}^{*+}$ scavenging activity of extract was determined according to the method described by Tangjitjaroenkun et al. [15]. The $\mathrm{ABTS}^{*+}$ was generated by reaction of $7 \mathrm{mmol}$ of ABTS in distilled water with $2.45 \mathrm{mmol}$ potassium persulfate $\left(\mathrm{K}_{2} \mathrm{~S}_{2} \mathrm{O}_{8}\right)$, and the mixture was incubated in the dark at room temperature for $16 \mathrm{~h}$ before use. The $\mathrm{ABTS}^{\circ+}$ solution was diluted with deionized water to get an absorbance of $0.80 \pm 0.02$ at $734 \mathrm{~nm} .50 \mu \mathrm{l}$ of each diluted extract was added to $450 \mu \mathrm{l}$ of $\mathrm{ABTS}^{\circ+}$ solution and its absorbance was recorded at $734 \mathrm{~nm}$ using spectrophotometer exactly $1 \mathrm{~min}$ after the initial mixing. Trolox was used as a positive control. The abilities to scavenge the ABTS radical were determined by the same equation that was used to calculate DPPH scavenging activity. According to the percentage ABTS radical scavenging, $\mathrm{IC}_{50}$ value was calculated as the concentration of extract required to reduce $50 \%$ of the initial ABTS free radicals. All the tests were performed in triplicate.

\section{Ferric reducing antioxidant power (FRAP) assay}

The total antioxidant capacity of extract was performed according to the FRAP of Szeto et al. [16] with some modifications. The fresh FRAP reagent was prepared from $300 \mathrm{mmol}$ acetate buffer ( $\mathrm{pH}$ 3.6), and $10 \mathrm{mmol}$ 2,4,6-Tris(2-pyridyl)-s-triazine (TPTZ) solution in $40 \mathrm{mmol}$ $\mathrm{HCl}$ and $20 \mathrm{mmol} \mathrm{FeCl} \cdot 6 \mathrm{H}_{2} \mathrm{O}$ solution in the ratio of 10:1:1 (v/v/v) and then incubated in a water bath at $37^{\circ} \mathrm{C}$ before use. The reaction mixture contained $60 \mu \mathrm{l}$ extract, distilled water $180 \mu \mathrm{l}$, and $1.8 \mathrm{ml}$ FRAP reagent and incubated for $4 \mathrm{~min}$. The absorbance of blue color was measured at $593 \mathrm{~nm}$. The standard curve was plotted using different concentrations in the range between 0.1 and $1 \mathrm{mmol}$. The antioxidant capacity of the extract was expressed as $\mathrm{mmol} \mathrm{FeSO}_{4} \cdot 7 \mathrm{H}_{2} \mathrm{O} / \mathrm{g}$ extract. All measurements were performed in triplicate.

\section{Statistical analysis}

The bioassays were performed in triplicates. The results were expressed as mean \pm standard deviation and statistically analyzed using Microsoft Excel package 2013 version. The $\mathrm{IC}_{50}$ values of the extract were calculated by linear regression analysis. 
The mass spectrometer (Varian Saturn GC/MS/MS 4D) was operated at an emission current of $10 \mu \mathrm{A}$ and an electron multiplier voltage between 1400 and $1500 \mathrm{~V}$. The trap temperature was set at $150^{\circ} \mathrm{C}$ and the transfer line temperature at $170^{\circ} \mathrm{C}$. Mass scanning was performed from 40 to $650 \mathrm{amu}$.

\section{RESULTS AND DISCUSSION}

The potent S. omiyaensis SCH2 strain isolated from mangrove sediment in Laem Sing district, Chanthaburi province, Thailand. This isolate was characterized base on morphology, chemotaxonomy, and physiology and 16S rDNA sequencing as described by Tangjitjaroenkun et al. [12]. In an earlier study, the fermentation time course for antibiotic production by S. omiyaensis SCH 2 indicated that the maximum antibacterial activity was obtained between 21 and 28 days of cultivation. The cell-free culture medium of the isolate exhibited antibacterial activity Gram-positive bacteria by disc diffusion method [12].

\section{Extraction and GC-MS analysis of SCH2 extract}

The fermentation was grown in ISP2 broth (30 l) with $3 \% \mathrm{NaCl}$ under continuous shaking for 21 days. The cell-free filtrate was extracted twice with ethyl acetate and concentrated under reduced pressure to yield $1.86 \mathrm{~g}$ of dark brown color crude residue. The SCH2 crude extract was analyzed by GC-MS (Table 1 ). The volatile chemical structure revealed presence of four compounds including an aromatic alcohol (2-phenylethanol), acetamide (2-phenylacetamide) and pyrrolopyrazines (pyrrolo[1,2-a]pyrazine-1,4-dione,hexahydro-3(2-methylpropyl)-, and pyrrolo[1,2-a]pyrazine-1,4-dione,hexahydro3-(phenylmethyl)-) (Fig. 1). Among these, the major constituent of isolate $\mathrm{SCH} 2$ was found to be 2-phenylacetamide (79\%) with a retention time of $24.43 \mathrm{~min}$. Including to this the three compounds such as pyrrolo[1,2-a]pyrazine-1,4-dione,hexahydro-3-(2methylpropyl)- (4.17\%), pyrrolo[1,2-a]pyrazine-1,4-dione,hexahydro3-(phenylmethyl) - $(0.41 \%)$, and 2-phenylethanol $(0.23 \%)$ also present in the extract with retention time $37.35,47.31$, and 11.34 min, respectively.

The GC-MS analysis revealed that the SCH2 extract was mainly composed of acetamide and pyrrolopyrazines. The acetamide in the extract, 2-phenylacetamide, has earlier been reported as the component in ethyl acetate extract of Streptomyces spp. CIBYL1, Streptomyces sp. BCC 21795 and Streptomyces coelicolor strain AOB KF977550 [11,17,18]. Ser et al. [5] also identified 2-phenylacetamide in the methanol extract of Streptomyces pluripotens MUSC 137 by GC-MS analysis. Our study has in accordance with the previous report, the pyrrolo1,2-a pyrazine group such as pyrrolo[1,2-a]pyrazine-1,4-dione,hexahydro-3-(2-methylpropyl)-, pyrrolo[1,2-a]pyrazine-1,4-dione,hexahydro-3-(phenylmethyl)- and 3 -isobutylhexahydropyrrolo[1,2-a]pyrazine-1,4-dione have been reported from the extracts of Streptomyces sp. MUM256, Streptomyces sp. isolate UPMRS4, Streptomyces albus $\mathrm{CN}-4$, and Streptomyces cavouresis KU-V39 [19-22].

\section{Antibacterial activity}

The ethyl acetate extract of $S$. omiyaensis SCH2 tested in the disc diffusion method showed antibacterial activity at a concentration of $100 \mu \mathrm{g} /$ disc. The results presented in Table 2 show that the SCH2 extract was active against B. subtilis, S. aureus, E. Cloacae, and K. pneumoniae with a diameter of inhibition zone of $17.28 \mathrm{~mm}, 9.45 \mathrm{~mm}, 22.12 \mathrm{~mm}$, and $17.52 \mathrm{~mm}$, respectively. The MIC and MBC values of the extract were determined by a broth microdilution method and presented in Table 2. The MIC value of the extract ranged from 0.125 to $2 \mathrm{mg} / \mathrm{ml}$, while the MBC ranged from 4 to $>8 \mathrm{mg} / \mathrm{ml}$. The lowest MIC value of $0.125 \mathrm{mg} / \mathrm{ml}$ was found against E. cloacae. The MIC value of $1 \mathrm{mg} / \mathrm{ml}$ was found against $K$. pneumoniae, whereas MIC value of $B$. subtilis was found to be $2 \mathrm{mg} / \mathrm{ml}$ (Fig. 2).

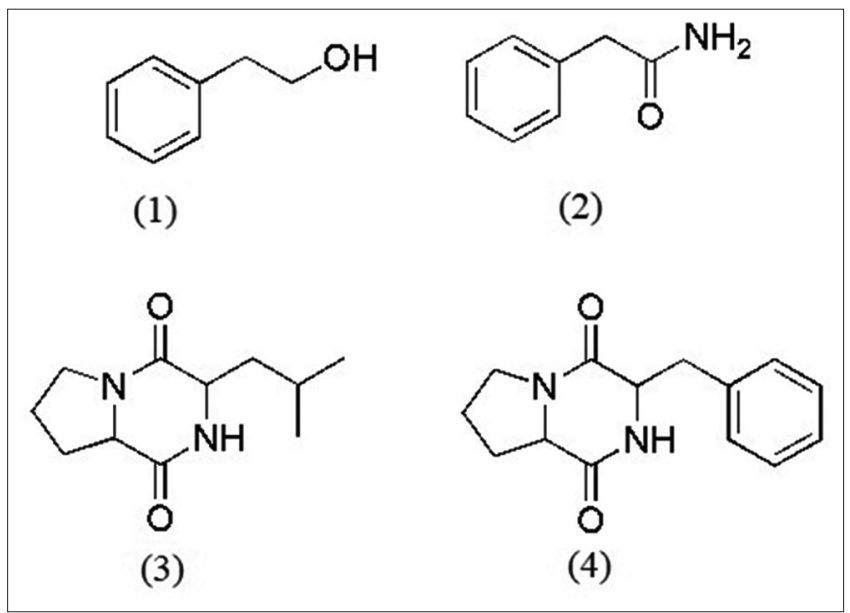

Fig. 1: Chemical structures of the identified compounds from SCH2 extract. (1) 2-phenylethanol; (2) 2-phenylacetamide;

(3) pyrrolo[1,2-a]pyrazine-1,4-dione,hexahydro-3-

(2-methylpropyl)-; and (4) pyrrolo[1,2-a]pyrazine-1,4dione,hexahydro-3-(phenylmethyl)-

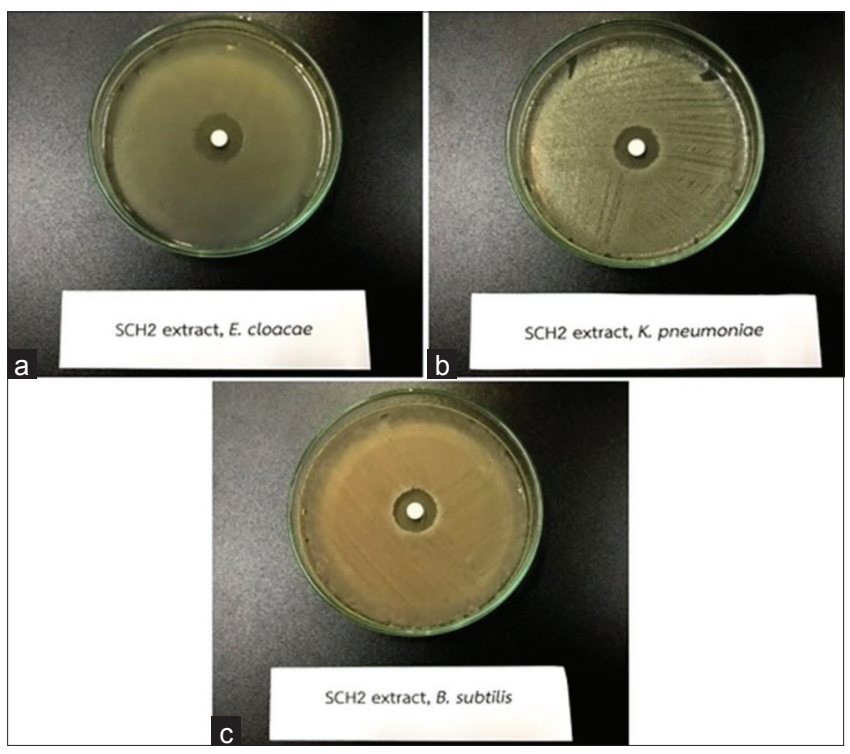

Fig. 2: Antibacterial activity of SCH2 extract on different test microorganisms. (a) Enterobacter cloacae; (b) Klebsiella pneumoniae; (c) Bacillus subtilis

Table 1: GC-MS analysis of volatile compounds in ethyl acetate extract of S. omiyaensis SCH2

\begin{tabular}{|c|c|c|c|c|c|}
\hline No. & Compounds & RT time (min) & Peak area (\%) & Molecular formula & Molecular weight $(\mathrm{g} / \mathrm{mol})$ \\
\hline 1 & 2-Phenylethyl alcohol & 11.34 & 0.23 & $\mathrm{C}_{6} \mathrm{H}_{5} \mathrm{CH}_{2} \mathrm{CH}_{2}$ & 122 \\
\hline 2 & 2-Phenylacetamide & 24.43 & 79.19 & $\mathrm{C}_{8}^{6} \mathrm{H}_{9}^{3} \mathrm{NO}^{2}$ & 135 \\
\hline 3 & $\begin{array}{l}\text { Pyrrolo[1,2-a] pyrazine-1,4-dione, } \\
\text { hexahydro-3-(2-methylpropyl)- }\end{array}$ & 37.35 & 4.17 & $\mathrm{C}_{11}^{8} \mathrm{H}_{18} \mathrm{~N}_{2} \mathrm{O}_{2}$ & 210 \\
\hline 4 & $\begin{array}{l}\text { Pyrrolo[1,2-a] pyrazine-1,4-dione, } \\
\text { hexahydro-3-(phenylmethyl)- }\end{array}$ & 47.31 & 0.41 & $\mathrm{C}_{14} \mathrm{H}_{16} \mathrm{~N}_{2} \mathrm{O}_{2}$ & 244 \\
\hline
\end{tabular}

GC-MS: Gas chromatography-mass spectrometry, S. omiyaensis: Streptomyces omiyaensis 
The results showed strong activity against Gram-negative bacteria (E. cloacae and $K$. pneumoniae), moderate activity against Grampositive bacteria (B. subtilis). Based on the chemical constituents identified using GC-MS, the compounds produced by S. omiyiensis SCH2, four compounds were found to possess the properties of antimicrobial. Earlier studies noticed that the volatile compound, 2-phenylethanol, from the extract of Streptomyces sp. ANU 6277 and Streptomyces platensis F-1 exhibited moderate antifungal property against phytopathogens [23,24]. Another study by Balachandran et al. [25] indicated that 2-phenylacetamide was an antibacterial compound detected with the highest peak area percentage of around 15.56\% in the ethyl acetate extract of Methylobacterium sp. ERI-135. Other compounds such as pyrrolo[1,2-a]pyrazine-1,4-dione,hexahydro-3(2-methylpropyl)- and pyrrolo[1,2-a]pyrazine-1,4-dione,hexahydro-3(phenylmethyl)- belong to pyrrolopyrazine group were also presented in various Streptomyces species [19-21]. Both of the pyrrolopyrazine exhibited potent antibacterial and anticandidal activity [26,27]. Therefore, the presence of these compounds in the extract of SCH2 could be the contributing factor responsible for antibacterial activity.

\section{Antioxidant activity}

The antioxidant activity of the SCH2 extract was evaluated by DPPH radical scavenging activity, ABTS free radical scavenging activity and FRAP activity assay (Table 3). In the DPPH assay, the extract was evaluated for antioxidant activity in term of hydrogen donating ability. The antioxidant compounds within the extract scavenge DPPH radicals (deep purple color) to light yellow color 1,1-diphenyl-2picryl hydrazine with decreasing of absorbance at $517 \mathrm{~nm}$ [28]. The ethyl acetate extract showed the scavenging activities of $17.09 \%$ at $500 \mu \mathrm{g} / \mathrm{ml}, 28.33 \%$ at $1,000 \mu \mathrm{g} / \mathrm{ml}, 40.88 \%$ at $1,500 \mu \mathrm{g} / \mathrm{ml}, 48.08$ at $2,000 \mu \mathrm{g} / \mathrm{ml}, 55.77 \%$ at $2,500 \mu \mathrm{g} / \mathrm{ml}, 62.54 \%$ at $3,000 \mu \mathrm{g} / \mathrm{ml}, 67.20 \%$ at $3,500 \mu \mathrm{g} / \mathrm{ml}$, and $73.39 \%$ at $4000 \mu \mathrm{g} / \mathrm{ml}$ (Fig. 3). IC $\mathrm{C}_{50}$ value (the

Table 2: Antibacterial activity of ethyl acetate extract of S. omiyaensis SCH2

\begin{tabular}{|c|c|c|c|c|c|c|c|c|c|}
\hline \multirow[t]{2}{*}{ Microorganisms } & \multicolumn{3}{|c|}{ SCH2 extract } & \multicolumn{3}{|c|}{ Chloramphenicol } & \multicolumn{3}{|l|}{ Penicillin G } \\
\hline & $\begin{array}{l}\text { DIZ } \\
(\mathrm{mm})\end{array}$ & $\begin{array}{l}\text { MIC } \\
(\mathrm{mg} / \mathrm{ml})\end{array}$ & $\begin{array}{l}\text { MBC } \\
(\mathrm{mg} / \mathrm{ml})\end{array}$ & $\begin{array}{l}\text { DIZ } \\
(\mathrm{mm})\end{array}$ & $\begin{array}{l}\text { MIC } \\
(\mathrm{mg} / \mathrm{ml})\end{array}$ & $\begin{array}{l}\text { MBC } \\
(\mathrm{mg} / \mathrm{ml})\end{array}$ & $\begin{array}{l}\text { DIZ } \\
(\mathrm{mm})\end{array}$ & $\begin{array}{l}\text { MIC } \\
(\mathrm{mg} / \mathrm{ml})\end{array}$ & $\begin{array}{l}\text { MBC } \\
(\mathrm{mg} / \mathrm{ml})\end{array}$ \\
\hline S. aureus ATCC 25923 & $9.45 \pm 0.29$ & $>8$ & $>8$ & $19.55 \pm 0.31$ & 0.0078 & 0.125 & $36.23 \pm 0.39$ & NT & NT \\
\hline S. saprophyticus ATCC 15305 & $0.00 \pm 0.00$ & $>8$ & $>8$ & $25.65 \pm 1.29$ & 0.0039 & 0.125 & $40.97 \pm 0.57$ & NT & NT \\
\hline E. coli ATCC 25922 & $0.00 \pm 0.00$ & $>8$ & $>8$ & $23.03 \pm 0.09$ & 0.0019 & 0.625 & $7.07 \pm 0.25$ & NT & NT \\
\hline P. aeruginosa ATCC 27853 & $0.00 \pm 0.00$ & $>8$ & $>8$ & $0.00 \pm 0.00$ & 0.0062 & 0.625 & $6.11 \pm 0.18$ & NT & NT \\
\hline S. typhimurium ATCC 13311 & $0.00 \pm 0.00$ & $>8$ & $>8$ & $28.40 \pm 0.86$ & 0.0019 & 0.125 & $22.83 \pm 0.11$ & NT & NT \\
\hline E. cloacae ATCC 23355 & $21.12 \pm 1.94$ & 0.125 & $>8$ & $41.05 \pm 0.07$ & 0.0031 & 0.200 & $37.68 \pm 0.06$ & NT & NT \\
\hline K. pneumoniae ATCC 13883 & $17.52 \pm 0.69$ & 1 & 4 & $21.12 \pm 0.38$ & 0.0062 & 0.200 & $35.45 \pm 0.29$ & NT & NT \\
\hline P. mirabilis DMST 8212 & $0.00 \pm 0.00$ & $>8$ & $>8$ & $12.67 \pm 0.25$ & 0.0313 & 0.125 & $22.37 \pm 1.55$ & NT & NT \\
\hline
\end{tabular}

DIZ: Diameter of inhibition zone, NT: Not test. S. omiyaensis: Streptomyces omiyaensis, MIC: Minimum inhibitory concentration, MBC: Minimum bactericidal concentration, B. subtilis: Bacillus subtilis, S. aureus: Staphylococcus aureus, S. saprophyticus: Staphylococcus saprophyticus, P. aeruginosa: Pseudomonas aeruginosa, E. coli: Escherichia coli, P. aeruginosa: Pseudomonas aeruginosa, S. typhimurium: Salmonella typhimurium, E. cloacae: Enterobacter cloacae, K. pneumonia: Klebsiella pneumonia, P. mirabilis: Proteus mirabilis

Table 3: Antioxidant activity of ethyl acetate extract of S. omiyaensis SCH2 and standards by DPPH, ABTS, and FRAP method

\begin{tabular}{|c|c|c|c|}
\hline Extract and standards & DPPH $\left(\mathrm{IC}_{50}, \mu \mathrm{g} / \mathrm{ml}\right)$ & ABTS $\left(\mathrm{IC}_{50}, \mu \mathrm{g} / \mathrm{ml}\right)$ & FRAP $\left(\mathrm{mmol} \mathrm{FeSO}_{4} \cdot 7 \mathrm{H}_{2} \mathrm{O} / \mathrm{gDW}\right)$ \\
\hline SCH2 extract & $2,078.13 \pm 24.58$ & $475.74 \pm 4.56$ & $110.36 \pm 1.75$ \\
\hline BHT & $32.59 \pm 2.60$ & - & - \\
\hline Trolox & - & $2.44 \pm 0.08$ & - \\
\hline
\end{tabular}

S. omiyaensis: Streptomyces omiyaensis, BHT: Butylated hydroxy toluene, $\mathrm{IC}_{50}$ : Inhibitory concentration, DPPH: 2,2-diphenyl-1-picryl-hydrazyl,

ABTS: 2,2'-azino-bis[3-ethylbenzothiazoline-6-sulphonic acid], FRAP: Ferric reducing antioxidant power

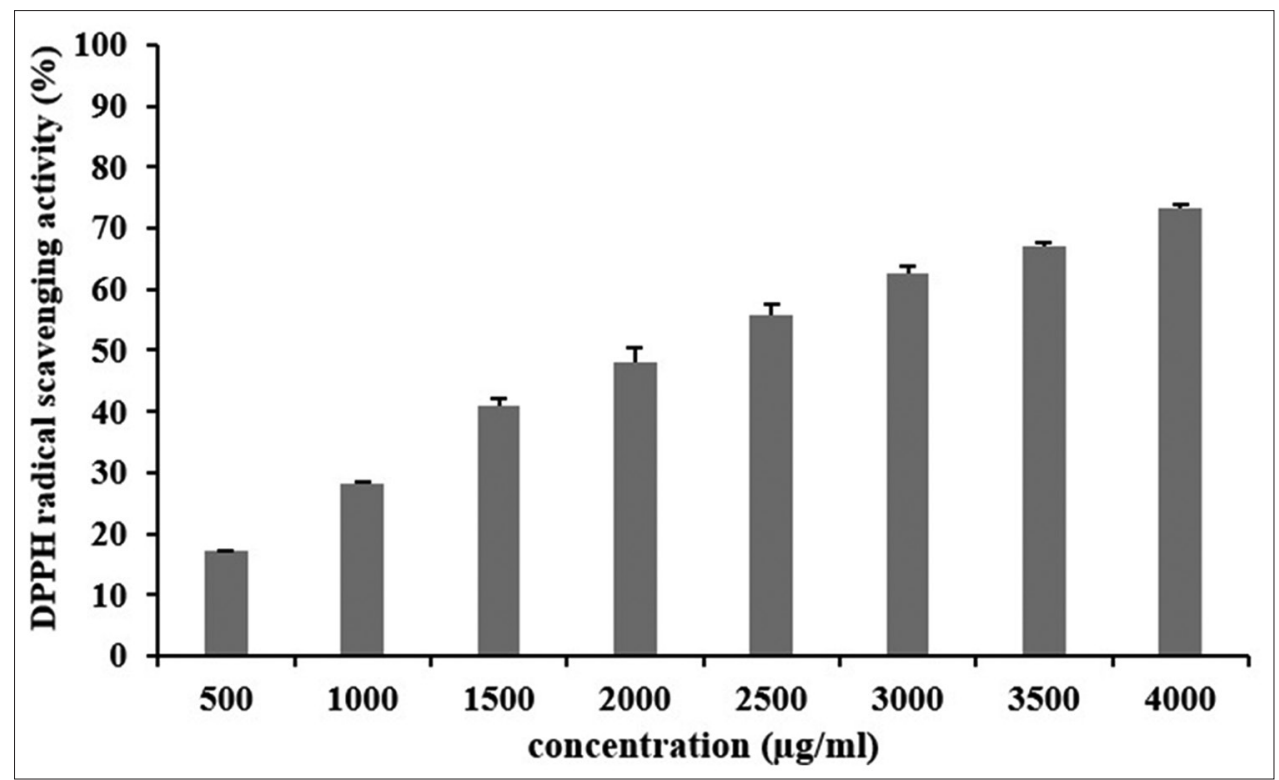

Fig. 3: 2,2-diphenyl-1-picryl-hydrazyl radical scavenging activity of the ethyl acetate extract from Streptomyces omiyaensis SCH2 


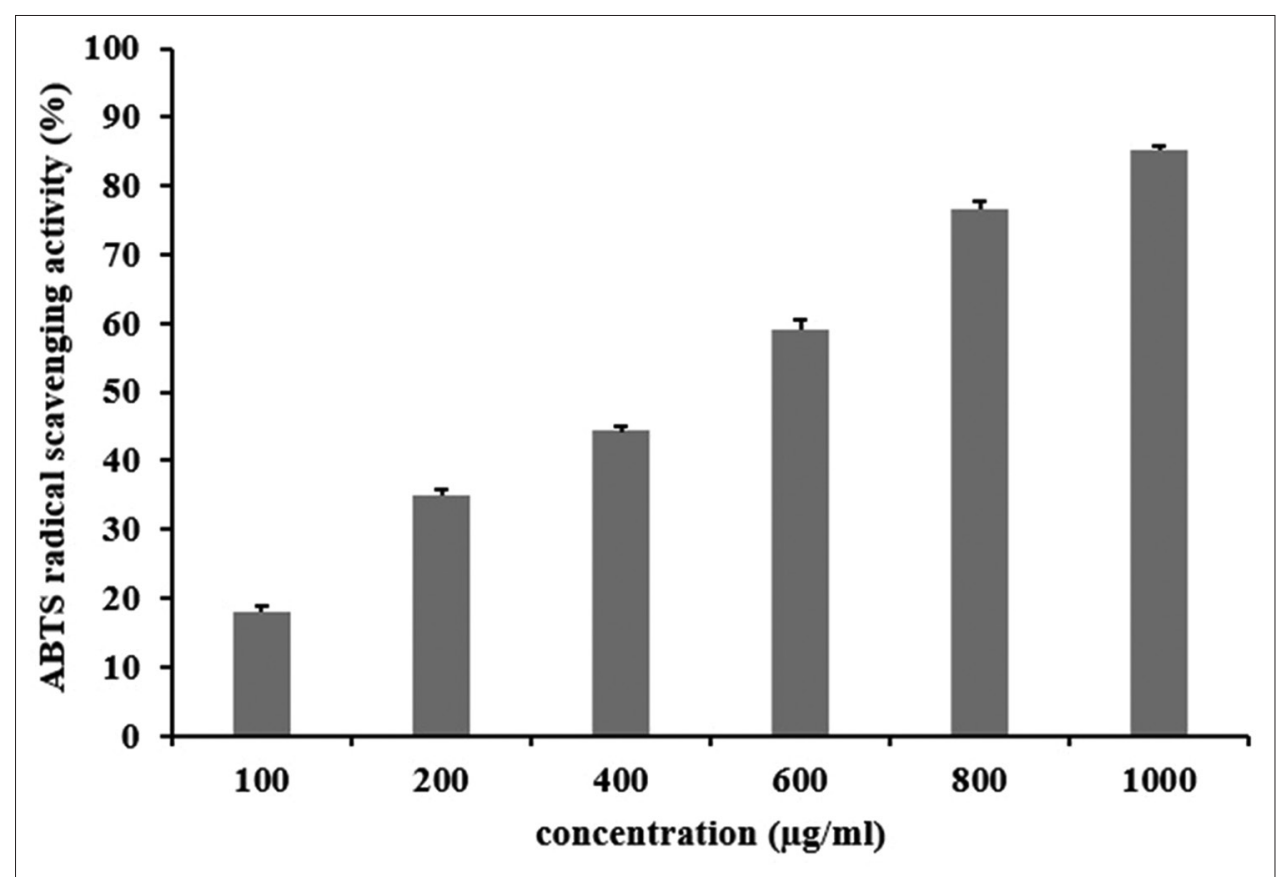

Fig. 4: 2,2'-azino-bis[3-ethylbenzothiazoline-6-sulphonic acid] radical scavenging activity of the ethyl acetate extract from Streptomyces omiyaensis $\mathrm{SCH} 2$

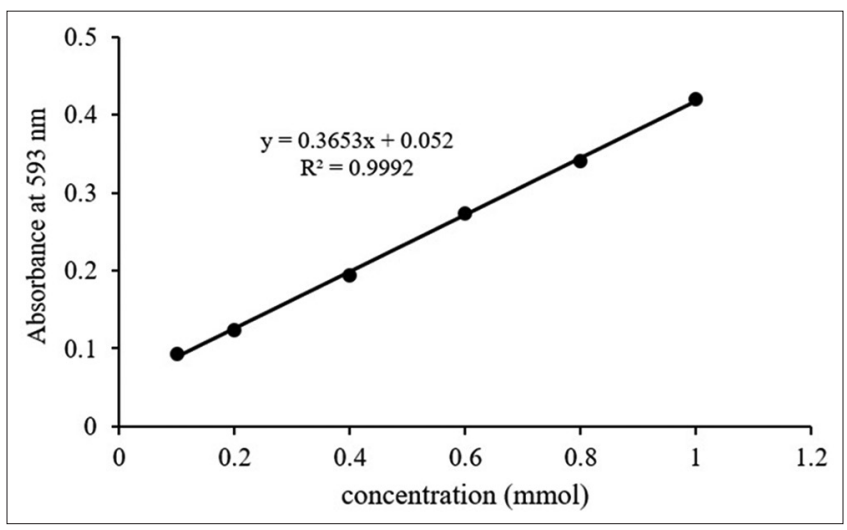

Fig. 5: Standard curve of ferric reducing antioxidant power assay using ferrous sulfate at a concentration between 0.1 and $1.0 \mathrm{mmol}$

concentration of extract that inhibits $50 \%$ of the DPPH radicals) was found to be $2,078.13 \pm 24.58 \mu \mathrm{g} / \mathrm{ml}$, while BHT as standard was found to have an $\mathrm{IC}_{50}$ of $32.59 \pm 2.60 \mu \mathrm{g} / \mathrm{ml}$.

ABTS radical scavenging assay is based on the scavenging of the radical cation $\left(\mathrm{ABTS}^{*}\right)$ by antioxidants in the extract. The $\mathrm{ABTS}^{*+}$ is generated through the reaction of ABTS and potassium persulfate. During the reaction, $\mathrm{ABTS}^{\circ+}$ develops an intense blue-green color with an absorption maximum at $734 \mathrm{~nm}$. In the presence of an antioxidant in the extract, the blue-green color of the ABTS ${ }^{*+}$ converted to colorless neutral form when the free radicals were scavenged by antioxidant [29]. The results showed that the ethyl acetate extract of S. omiyaensis had ABTS radical scavenging activity. The inhibition of the extract was $17.41 \%$ at $100 \mu \mathrm{g} / \mathrm{ml}, 34.78 \%$ at $200 \mu \mathrm{g} / \mathrm{ml}, 43.97 \%$ at $400 \mu \mathrm{g} / \mathrm{ml}, 59.81 \%$ at $600 \mu \mathrm{g} / \mathrm{ml}, 77.14 \%$ at $800 \mu \mathrm{g} / \mathrm{ml}$, and $85.26 \%$ at $1,000 \mu \mathrm{g} / \mathrm{ml}$ (Fig. 4). The $\mathrm{IC}_{50}$ of ABTS reducing the activity of SCH2 extract was $475.74 \pm 4.56 \mu \mathrm{g} /$ $\mathrm{ml}$ while the standard antioxidant Trolox was $2.44 \pm 0.08 \mu \mathrm{g} / \mathrm{ml}$.

The FRAP assay is evaluated based on the reduction of the ferrictripyridyltriazine ( $\mathrm{Fe}^{3+}$-TPTZ) complex to the ferrous tripyridyltriazine
$\left(\mathrm{Fe}^{2+}\right.$-TPTZ) by antioxidants in the extract. The ferrous form can be monitored by measuring the intensity of the blue color and absorbed at $593 \mathrm{~nm}$ [30]. The standard curve was plotted in the range of 0.1-1 mmol of ferrous sulfate $\left(\mathrm{FeSO}_{4} \cdot 7 \mathrm{H}_{2} \mathrm{O}\right)$ and the result was expressed as mmol $\mathrm{FeSO}_{4} \cdot 7 \mathrm{H}_{2} \mathrm{O}$ equivalent per gram of extract (Fig. 5). The ethyl acetate extract of $S$. omiyaensis showed FRAP value as $110.36 \pm 1.75$ equivalent mmol $\mathrm{FeSO}_{4} \cdot 7 \mathrm{H}_{2} \mathrm{O} / \mathrm{g}$ extract.

The SCH2 extract showed antioxidant activities in a dose-dependent manner in DPPH and ABTS radical scavenging activities. Our results demonstrated that the differential scavenging activities of the antioxidant compounds in the SCH2 extract against DPPH, ABTS, and $\mathrm{Fe}^{3+}$ radicals may be referred to the different mechanisms of the radicalantioxidant reactions. The extract has the capacity to scavenge free radicals through hydrogen transfer reaction for the DPPH assay and single electron transfer reaction for the ABTS assay, while the FRAP assay is used to measure the reducing potential of an antioxidant. Based on the results of GC-MS analysis, SCH2 extract revealed the presence of pyrrolizidines, including pyrrolo[1,2-a]pyrazine-1,4-dione,hexahydro3-(2-methylpropyl)- and pyrrolo[1,2-a]pyrazine-1,4-dione,hexahydro3-(phenylmethyl)-. The pyrrolizidine compounds from Streptomyces extracts have been founded to possess potent antioxidant properties in the previous studies $[21,31,32]$. These data suggest that both pyrrolizidine compounds in the $\mathrm{SCH} 2$ extract were able to scavenge or reduce free radicals as evaluated for antioxidant activity by different antioxidant assays.

\section{CONCLUSION}

The ethyl acetate extract of S. omiyaensis SCH2 exhibited potent antibacterial and antioxidant properties. The extract showed dosedependent free radical scavenging capacity and reducing power by different in vitro assay. Furthermore, the extract also has antibacterial activity against $K$. pneumoniae, E. cloacae, and B. subtilis. The acetamide and pyrrolopyrazine compounds present in the extract could be responsible for the antibacterial and antioxidant activity observed. The findings of this study revealed that $\mathrm{S}$. omiyaensis $\mathrm{SCH} 2$ has been found to produce secondary metabolites such as antibacterial and antioxidant compounds. Further studies are required to isolate and elucidate the bioactive components from the extract. 


\section{ACKNOWLEDGMENT}

The author is grateful to the Kasetsart University Research and Development (KURDI) (grant number 20420176010046000) and Faculty of Science at Siracha, Kasetsart University, for the financial support granted to this research project.

\section{AUTHOR'S CONTRIBUTION}

Tangjitjaroenkun $\mathrm{J}$ is responsible for study design, analysis, and manuscript preparation.

\section{CONFLICTS OF INTEREST}

Conflicts of interest declare none.

\section{REFERENCES}

1. Solecka J, Zajko J, Postek M, Rajnisz A. Biologically active secondary metabolites from actinomycetes. Cent Eur J Biol 2012;7:373-90.

2. Bérdy J. Bioactive microbial metabolites. J Antibiot 2005;58:1-26.

3. Duddu MK, Guntuku G. Isolation, screening and characterization of antibiotic producing actinomycetes from Kapuluppada plastic waste dumping yard, Visakhapatnam. Int J Pharm Pharm Sci 2016;8:221-9.

4. Wang C, Wang Z, Qiao X, Li Z, Li F, Chen M, et al. Antifungal activity of volatile organic compounds from Streptomyces alboflavus TD-1. FEMS Microbiol Lett 2013;341:45-51.

5. Ser H, Mutalib AB, Yin N, Chan K, Goh B, Lee L. Evaluation of antioxidative and cytotoxic activities of Streptomyces pluripotens MUSC 137 isolated from mangrove soil in Malaysia. Front Microbiol 2015;6:1398.

6. Chawawisit K, Bhoopong P, Phupong W, Lertcanawanichakul M. Antimicrobial and cytotoxic activities of bioactive compounds produced by Streptomyces sp. KB1. Int J Pharm Pharm Sci 2015;7:118-22.

7. Schatz A, Bugie E, Waksman SA. Streptomycin, a substance exhibiting antibiotic activity against gram-positive and gram-negative bacteria. Clin Orthop Relat Res 2005;437:3-6.

8. Khosla C. Structures and mechanisms of polyketide synthases. J Org Chem 2009;74:6416-20.

9. Kollef MH. New antimicrobial agents for methicillin-resistant Staphylococcus aureus. Crit Care Resusc 2009;11:282-6.

10. Citron CA, Gleitzmann J, Laurenzano G, Pukall R, Dickschat JS. Terpenoids are widespread in actinomycetes: A correlation of secondary metabolism and genome data. Chem Biochem 2012;13:202-14.

11. Kornsakulkarn J, Saepua S, Srijomthong K, Rachtawee P, Thongpanchang C. Quinazolinone alkaloids from actinomycete Streptomyces sp. BCC 21795. Phytochem Lett 2015;12:6-8.

12. Tangjitjaroenkun J, Tangchitcharoenkhul R, Yahayo W, Supabphol R. In vitro antimicrobial and cytotoxic activities of mangrove actinomycetes from eastern Thailand. Chiang Mai J Sci 2017:44:322-37.

13. CLSI. Clinical and Laboratory Standards Institute. Performance Standards for Antimicrobial Disk and Dilution Susceptibility Tests for Bacteria Isolated from Animals: $2^{\text {nd }}$ ed. Approved Standard CLSI/ NCCLS document M02-A11. Wayne, PA, USA: CLSI; 2002b.

14. Sarker SD, Nahar L, Kumarasamy Y. Microtiter-plate-based antibacterial assay incorporating resazurin as an indicator of cell growth, and its application in the in vitro antibacterial screening of phytochemicals. Methods 2007;42:321-4
15. Tangiitjaroenkun J, Supabphol R, Chavasiri W. Antioxidant effect of Zanthoxylum limonella Alston. J Med Plant Res 2012;6:1407-14.

16. Szeto YT, Chu WK, Benzie IF. Antioxidants in fruits and vegetables: A study of cellular availability and direct effects on human DNA. Biosci Biotech Biochem 2006;70:2551-5.

17. Pu X, Li G, Yang T, Li G, Yi J, Zhang G, et al. A new cyclododeca[d] oxazole derivative from Streptomyces spp. CIBYL1. Nat Prod Res 2013;27:603-8.

18. Odumosu BT, Buraimoh OM, Okeke CJ, Ogah JO, Michel FC. Antimicrobial activities of the Streptomyces ceolicolor strain AOB KF977550 isolated from a tropical estuary. J Taibah Univ Sci 2017;11:836-41.

19. Tan LT, Ser HL, Yin WF, Chan KG, Lee LH, Goh BH. Investigation of antioxidative and anticancer potentials of Streptomyces sp. MUM256 isolated from Malaysia mangrove soil. Front Microbiol 2015;6:1316.

20. Awla HK, Kadir J, Othman R, Rashid TS, Wong MY. Bioactive compounds produced by Streptomyces sp. isolate UPMRS4 and antifungal activity against Pyricularia oryzae. Am J Plant Sci 2016;7:1077-85.

21. Narasaiah BC. Structural elucidation and antimicrobial activity of secondary metabolites from Streptomyces albus CN-4. Int J Res Eng Appl Sci 2016;6:77-89.

22. Narendhran S, Rajiv P, Vanathi P, Sivaraj R. Spectroscopic analysis of bioactive compounds from Streptomyces cavouresis KUV39: Evaluation of antioxidant and cytotoxicity activity. Int J Pharm Pharm Sci 2014;6:319-22

23. Narayana KJ, Prabhakar P, Vijayalakshmi M, Venkateshwarlu Y, Krishna PS. Study on Bioactive compounds from Streptomyces sp. ANU 6277. Pol J Microbiol 2008;57:35-9.

24. Wan M, Li G, Zhang J, Jiang D, Huang HC. Effect of volatile substances of Streptomyces platensis F-1 on control of plant fungal diseases. Biol Control 2008;46:552-9.

25. Balachandran C, Duraipandiyan V, Ignacimuthu S. Cytotoxic (A549) and antimicrobial effects of Methylobacterium sp. Isolate (ERI-135) from Nilgiris forest soil, India. Asian Pac J Trop Biomed 2012;2:712-6.

26. Melo IS, Santos SN, Rosa LH, Parma MM, Silva LJ, Queiroz SC, et al. Isolation and biological activities of an endophytic Mortierella alpine strain from the antractic moss Schistidium antarctici. Extremophiles 2014; 18:15-23.

27. Sanjenbam P, Gopal JV, Kannabiran K. Isolation and identification of anticandidal compound from Streptomyces sp. VITPK9. Appl Biochem Microbiol 2014;50:492-9.

28. Shon MY, Kim TH, Sung NJ. Antioxidants and free radical scavenging activity of Phellinus baumii (Phellinus of Hymenochaetaceae) extracts. Food Chem 2003;82:593-7.

29. Miller NJ, Rice-Evans CA. Factors influencing the antioxidant activity determined by the $\mathrm{ABTS}^{+}$radical cation assay. Free Radical Res 1997;26:195-9.

30. Huang D, Ou B, Prior RL. The chemistry behind antioxidant capacity assays. J Agri Food Chem 2005;53:1841-56.

31. Ser HL, Palanisamy UD, Yin WF, Abd Malek SN, Nurestri S, Chan, KG, et al.Presence of antioxidative agent, pyrrolo [1, 2-a] pyrazine-1, 4-dione, hexahydro-in newly isolated Streptomyces mangrovisoli $\mathrm{sp}$. nov. Front Microbiol 2015;6:854

32. Ser HL, Palanisamy UD, Yin WF, Chan KG, Goh BH, Lee LH. Streptomyces malaysiense sp. nov.: A novel Malaysian mangrove soil actinobacterium with antioxidative activity and cytotoxic potential against human cancer cell lines. Sci Rep 2016;6:24247. 